\title{
Global Air Quality and COVID-19 Pandemic: Do We Breathe Cleaner Air?
}

Aerosol and Air Quality

Research

\section{Special Issue:}

Special Issue on COVID-19 Aerosol Drivers, Impacts and Mitigation (XII)

\section{OPEN ACCESS}

Received: September 19, 2020 Revised: December 15, 2020 Accepted: January 28, 2021

\section{${ }^{*}$ Corresponding Author:} mehdi.torkmahalleh@nu.edu.kz

\section{Publisher:}

Taiwan Association for Aerosol Research

ISSN: $1680-8584$ print

ISSN: 2071-1409 online

cc) Copyright: The Author(s). This is an open access article distributed under the terms of the Creative Commons Attribution License (CC BY 4.0), which permits unrestricted use, distribution, and reproduction in any medium, provided the original author and source are cited.
Mehdi Amouei Torkmahalleh ${ }^{1 *}$, Zarina Akhmetvaliyeva ${ }^{1}$, Ali Darvishi Omran ${ }^{2}$, Faezeh Darvish Omran ${ }^{3}$, Mohadeseh Kazemitabar ${ }^{3}$, Mahtab Naseri ${ }^{3}$, Motahareh Naseri ${ }^{1}$, Hamed Sharifi ${ }^{3}$, Milad Malekipirbazari ${ }^{4}$, Enoch Kwasi Adotey ${ }^{1}$, Soudabeh Gorjinezhad ${ }^{1,5}$, Neda Eghtesadi ${ }^{1}$, Sergei Sabanov 6 , Andrés Alastuey ${ }^{7}$, María de Fátima Andrade ${ }^{8}$, Giorgio Buonanno ${ }^{5,9}$, Samara Carbone ${ }^{10}$, Diego Ernesto Cárdenas-Fuentes ${ }^{11}$, Flemming R. Cassee ${ }^{12,13}$, Qili Dai ${ }^{14}$, Andrés Henríquez ${ }^{15}$, Philip K. Hopke ${ }^{16}$, Petri Keronen ${ }^{17}$, Haider Abbas Khwaja ${ }^{18,19}$, Jong Kim ${ }^{20}$, Markku Kulmala ${ }^{17}$, Prashant Kumar ${ }^{21}$, Jonilda Kushta ${ }^{22}$, Joel Kuula23, Jordi Massagué7, Tamsin Mitchell ${ }^{24}$, Dennis Mooibroek ${ }^{12}$, Lidia Morawska ${ }^{9}$, Jarkko V. Niemi ${ }^{25}$, Soulemane Halif Ngagine ${ }^{26}$, Michael Norman ${ }^{27}$, Beatríz Oyama ${ }^{8}$, Pedro Oyola ${ }^{15}$, Fatma Öztürk ${ }^{28}$, Tuukka Petäjä ${ }^{17}$, Xavier Querol ${ }^{7}$, Yousef Rashidi ${ }^{29}$, Felipe Reyes ${ }^{15}$, Matthew Ross-Jones ${ }^{30}$, Tunga Salthammer ${ }^{31}$, Chrysanthos Savvides ${ }^{32}$, Luca Stabile ${ }^{5}$, Karin Sjöberg ${ }^{33}$, Karin Söderlund ${ }^{31}$, Ramya Sunder Raman ${ }^{34,35}$, Hilkka Timonen ${ }^{23}$, Masakazu Umezawa ${ }^{36}$, Mar Viana ${ }^{7}$, Shanju $\mathrm{Xie}^{37}$

${ }^{1}$ Department of Chemical and Materials Engineering, School of Engineering and Digital Sciences, Nazarbayev University, Nur-Sultan, 010000, Kazakhstan

${ }^{2}$ School of Civil and Environmental Engineering, Iran University of Science and Technology, Tehran, Iran

${ }^{3}$ Department of Ambient Air Quality, Rizgard Payesh Asman LLP., Tehran, 1484667536, Iran

${ }^{4}$ Department of Industrial Engineering, Bilkent University, Bilkent, Ankara, 06800, Turkey

${ }^{5}$ Department of Civil and Mechanical Engineering, University of Cassino and Southern Lazio, via Di Biasio 43, Cassino 03043, Italy

${ }^{6}$ Department of mining, School of Mining and Geosciences, Nazarbayev University, Nur-Sultan, Kazakhstan

${ }^{7}$ Institute of Environmental Assessment and Water Research (IDAEA-CSIC), Spanish Research Council - CSIC, C/ Jordi Girona 18, 08034 Barcelona, Spain

${ }^{8}$ Institute of Astronomy, Geophysics and Atmospheric Science, University of São Paulo, Brazil

${ }^{9}$ International Laboratory for Air Quality and Health, Science and Engineering Faculty, Queensland University of Science and Technology, 2 George Street, Brisbane, Queensland 4001, Australia

${ }^{10}$ Federal University of Uberlandia, Agrarian Sciences Institute, Uberlandia, Brazil

${ }^{11}$ School of Engineering and Sciences, Tecnológico de Monterrey, Monterrey, Mexico

${ }^{12}$ National Institute for Public Health and the Environment (RIVM), PO box 1, 3720 BA

Bilthoven, The Netherlands

${ }^{13}$ Institute for Risk Assessment Sciences, Utrecht University, Yalelaan 2, 3584 CM Utrecht, The Netherlands

${ }^{14}$ State Environmental Protection Key Laboratory of Urban Ambient Air Particulate Matter Pollution Prevention and Control, College of Environmental Science and Engineering, Nankai University, Tianjin, 300350, China

${ }^{15}$ Centro Mario Molina Chile, Antonio Bellet 292/602, Santiago, Chile

${ }^{16}$ Department of Public Health Sciences, University of Rochester Medical Center, Rochester, NY, 14642, USA

${ }^{17}$ Institute for Atmospheric and Earth System Research (INAR) / Physics, PO. Box 64, 00014, 
University of Helsinki, Finland

${ }^{18}$ Wadsworth Center, New York State Department of Health, Albany, NY, USA

${ }^{19}$ Department of Environmental Health Sciences, School of Public Health, University at Albany, Albany, New York, USA

${ }^{20}$ Department of Civil and Environmental Engineering, School of Engineering and Digital Sciences, Nazarbayev University, Nur-Sultan, 010000, Kazakhstan

${ }^{21}$ Global Centre for Clean Air Research (GCARE), Department of Civil and Environmental Engineering, Faculty of Engineering and Physical Sciences, University of Surrey, Guildford GU2 7XH, Surrey, UK

${ }^{22}$ The Cyprus Institute, Climate and Atmosphere Research Center (CARE-C), 2121, Nicosia, Cyprus

${ }^{23}$ Atmospheric Composition Research, Finnish Meteorological Institute, P.O.Box 503, 00101 Helsinki, Finland

${ }^{24}$ Environmental Science Department, Greater Wellington Regional Council, Manners St, Wellington 6142, New Zealand

${ }^{25}$ Helsinki Region Environmental Services Authority (HSY), PO Box 100, FI-00066, Helsinki, Finland

${ }^{26}$ Laboratoire de Physico-Chimie de I'Atmosphère, Université du Littoral Côte d'Opale, 59140

Dunkerque, France

${ }^{27}$ Environment and health administration, City of Stockholm, S-104 20 Stockholm, Sweden

${ }^{28}$ Environmental Engineering Department, Faculty of Engineering, Bolu Abant Izzet Baysal University (BAIBU), Golkoy Campus, 14030, Bolu, Turkey

${ }^{29}$ Environmental Sciences Research Institute, Shahid Beheshti University, Tehran, Iran

${ }^{30}$ Swedish Environmental Protection Agency, Stockholm, Sweden

${ }^{31}$ Department of Material Analysis and Indoor Chemistry, Fraunhofer WKI, 38108

Braunschweig, Germany

${ }^{32}$ Air Quality Section, Department of Labour Inspection, Ministry of Labour Welfare and Social Insurance of the Republic of Cyprus, Nicosia, Cyprus

${ }^{33}$ Swedish Environmental Research Institute, Environmental Intelligence, Gothenburg, Sweden

${ }^{34}$ Department of Earth and Environmental Sciences, Indian Institute of Science Education and Research (IISER) Bhopal, India

${ }^{35}$ Center for Research on Environment and Sustainable Technologies Indian Institute of Science Education and Research Bhopal, Bhopal Bypass Road, Bhauri, Bhopal - 462 066, Madhya Pradesh, India

${ }^{36}$ Department of Materials Science and Technology, Faculty of Industrial Science and Technology, Tokyo University of Science, Tokyo 125-8585, Japan

${ }^{37}$ Research \& Evaluation Unit (RIMU), Auckland Council, Auckland, New Zealand

\section{ABSTRACT}

The global spread of Severe Acute Respiratory Syndrome Coronavirus 2 (SARS-CoV-2) has challenged most countries worldwide. It was quickly recognized that reduced activities (lockdowns) during the Coronavirus Disease of 2019 (COVID-19) pandemic produced major changes in air quality. Our objective was to assess the impacts of COVID-19 lockdowns on groundlevel $\mathrm{PM}_{2.5}, \mathrm{NO}_{2}$, and $\mathrm{O}_{3}$ concentrations on a global scale. We obtained data from 34 countries, 141 cities, and 458 air monitoring stations on 5 continents (few data from Africa). On a global average basis, a $34.0 \%$ reduction in $\mathrm{NO}_{2}$ concentration and a $15.0 \%$ reduction in $\mathrm{PM}_{2.5}$ were estimated during the strict lockdown period (until April 30, 2020). Global average $\mathrm{O}_{3}$ concentration increased by $86.0 \%$ during this same period. Individual country and continent-wise comparisons have been made between lockdown and business-as-usual periods. Universally, $\mathrm{NO}_{2}$ was the pollutant most affected by the COVID-19 pandemic. These effects were likely because its emissions were from sources that were typically restricted (i.e., surface traffic and non-essential industries) by the lockdowns and its short lifetime in the atmosphere. Our results indicate that lockdown measures and resulting reduced emissions reduced exposure to most harmful pollutants and could provide global-scale health benefits. However, the increased $\mathrm{O}_{3}$ may have 
substantially reduced those benefits and more detailed health assessments are required to accurately quantify the health gains. At the same, these restrictions were obtained at substantial economic costs and with other health issues (depression, suicide, spousal abuse, drug overdoses, etc.). Thus, any similar reductions in air pollution would need to be obtained without these extensive economic and other consequences produced by the imposed activity reductions.

Keywords: SARS-CoV-2, Global air quality, $\mathrm{PM}_{2.5}, \mathrm{NO}_{2}, \mathrm{O}_{3}, \mathrm{COVID}-19$ pandemic

\section{INTRODUCTION}

The novel coronavirus was renamed by the International Committee on Taxonomy of Viruses as severe acute respiratory syndrome coronavirus-2 (SARS-CoV-2) (Lai et al., 2020; Secon et al., 2020). On January 11, 2020, the first death of Coronavirus Disease of 2019 (COVID-19) in China was reported. The first case of COVID-19 outside China was registered in Thailand on January 13, 2020. Since then, COVID-19 has rapidly spread around the globe. On January 20, February 19, and February 20, 2020, the first cases of COVID-19 were observed in the US, Iran, and Italy, respectively (Johns Hopkins Coronavirus Resource Center https://coronavirus.jhu.edu/map.html). The number of confirmed cases has grown exponentially in most affected countries creating a global concern such that on March 11, 2020, WHO declared the outbreak as a pandemic situation (Gupta, 2020).

As the number of confirmed cases continues to rise, not only global health but also the global economy, social networks, global transportation, and air quality are being profoundly affected. Stories in national and international media reported improvements in ambient air quality. They raised the question for the general public and the governments as to whether local and global air quality improvements should be expected. Researchers have begun to report the impact of the COVID-19 pandemic on air quality. To date, published studies have addressed air quality during the COVID-19 outbreak on a country-level scale in multiple countries, including Europe (Andree, 2020; Collivignarelli et al., 2020; Nakada and Urban, 2020; Tobías et al., 2020; Velders et al., 2020; Zoran et al., 2020), Asia (Mahato et al., 2020; Sharma et al., 2020; Wang and Su, 2020; Xu et al., 2020), the Americas (Adhikari and Yin, 2020; Berman and Ebisu, 2020; Nakada and Urban, 2020; Siciliano et al., 2020). Few studies exist in the literature that addressed air quality at the global scale during the pandemic (Bauwens et al., 2020; Lal et al., 2020; Le Quéré et al., 2020), and a clear assessment of its global impact has not yet been provided. Daily global $\mathrm{CO}_{2}$ emissions were reduced by $17 \%$ (Le Quéré et al., 2020). Satellite data showed reductions in $\mathrm{CO}, \mathrm{NO}_{2}$, and Aerosol Optical Depth (AOD) globally (Bauwens et al., 2020; Lal et al., 2020). However, satellite data reflect the total air column values making it difficult to conclude the health-relevant air pollution near the ground.

Nitrogen dioxide $\left(\mathrm{NO}_{2}\right)$, a short-lived gas, $\mathrm{O}_{3}$, a major atmospheric oxidant, and $\mathrm{PM}_{2.5}$ are important pollutants with climate, ecosystem, and health impacts. Exposure to these pollutants can induce oxidative stress and systemic inflammation that can reduce the host's immunity against bacterial and viral infections (Ciencewicki and Jaspers, 2007; Carugno et al., 2016). Thus, it is imperative to understand the changes and trends of these pollutants in the atmosphere during the COVID-19 pandemic period.

This study aimed to assess the impact of the COVID-19 pandemic on ambient air quality.

\section{METHOD}

\subsection{Sampling}

Three main criteria air pollutants that are widely monitored across the globe, including $\mathrm{PM}_{2.5}$, $\mathrm{O}_{3}$, and $\mathrm{NO}_{2}$ were analyzed to represent the global air quality. The validated concentration data were extracted from local stations of the air-monitoring organizations and/or their official websites as well as from open sources for the period from January 1, 2015 until April 30, 2020. All data presented in this work are average daily data that were mostly converted from 1-hour or 1-minute resolution depending on the data source. More details about data validation are presented in SI. 
Countries were selected based on the availability of the air quality data, the severity of the COVID-19 outbreak, and the level of air pollution. Briefly, five continents, including 34 countries, 141 cities, and 458 air monitoring stations, were investigated. The name of the countries, cities, types of monitoring stations and air pollutants, and chosen calendar period studied in this article are presented in Table S1. The detailed sampling information regarding each city is found in the Methodology section of the Supplementary Materials.

\subsection{Data Validation}

The validation process may vary in different countries. However, typically outliers and suspected data are flagged. Some of these flagged data are evaluated monthly by experts. Evaluations consist of checking the flags and comparing data with other nearby stations. If there is a valid reason to reject outliers or other flagged data, the data are rejected. An additional annual evaluation might be conducted for the whole data. PM data are calibrated against reference measurements and subsequently corrected.

\subsection{Statistical Analysis}

To understand the impact of COVID-19 on the air quality, two main methods, including Pairwise Comparison and Time Series Decomposition were implemented.

\subsection{Pairwise Comparison}

\subsubsection{Method IA}

This section aims to compare the mean monthly values of $\mathrm{PM}_{2.5}, \mathrm{O}_{3}$ and $\mathrm{NO}_{2}$ concentrations between 2020 and the respective average of 2017-2019 for all cities (if data were available) from January till the end of April. Firstly, a normality test was carried out for each given month. If it failed, the Signed Rank test was used; otherwise, the paired t-test was carried out. The threshold for a significant change was set to $\alpha \leq 0.05$. If data for a given city was missing for the period 2017-2019, then 2018-2019 was used or only 2019 (depending on the availability of the data); otherwise, this method was skipped for the given city. This method minimizes seasonal effects. However, this method might not truly examine the effect of COVID-19 if significant changes in the sources of emissions occur in 2020 compared to previous years.

\subsubsection{Method IB}

In this method, only 2020 data were used. We first identified the date and measures the government took to prevent the spread of the COVID-19 (Table S2), including the date for observing the first case of COVID-19, national/local recommendation, national/local lockdown, and easing lockdown. Then, the 2020 period was divided into five sub-periods including (before the first case (1), first case until the beginning of the local or national recommendation (whatever comes earlier) (2), local or national recommendation period (3), local or national lockdown period (whatever comes earlier) (4) Eased lockdown (5). ANOVA on Ranks test was carried out among each pair of the time period to understand how the governmental policy could impact the air quality during the COVID-19 spread in the given country. Although the lockdown dates are available for the countries in this study, we do not know the exact date of the recommendation or lockdown action for the given city. Thus, the dates for the local recommendation and local lockdown specified in Table S2 for a given country were considered for all cities of that country in this study.

This method ignores the seasonal variations of the pollutant concentrations. In the northern hemisphere, the reductions in the concentration over time in 2020 could occur due to the higher planetary boundary layer as temperature increases from January to March. The situation is reverse in the southern hemisphere.

\subsubsection{Time Series Decomposition}

We performed the statistical analyses in R language, and we employed STL function from "seasonal" package for the decomposition. Method of STL, Seasonal and Trend decomposition using Loess, is an adaptable and robust method for the time series decomposition (Cleveland et al., 1990). 
Time series data usually contain different types of patterns, and in order to capture the underlying patterns of our time series data, we first need to decompose it into several components, each of which represents a different structure in the data (Karavoulias, 2020). Time Series Decomposition is a statistical task in which we deconstruct the data into several parts. Assuming an additive decomposition, we can consider our time series constructed from three components of trend, seasonal and irregular elements. So, we can describe our time series at time $t\left(y_{t}\right)$ as:

$y_{t}=T_{t}+S_{t}+I_{t}$

Description of each element in our time series decomposition is as follows:

- $\quad T_{t}$ : The trend component at time $t$ represents the long-term evolution of the time series. This element exists in the data when there is a persistent increase or decrease.

- $S_{t}$ : The seasonal component at time $t$ describes the seasonal variations of our time series, which happens over a fixed and known period. Our time series consists of yearly seasonality.

- $\quad l_{t}$ : The irregular component at time $t$ reflects randomness in our data and characterizes the remainder of our time series after removing the trend and seasonality components.

To conclude if the governmental preventive measures due to the COVID-19 led to a certain change in the pollutant concentrations, all the three statistical methods have to demonstrate the impact of the COVID-19. Firstly, the average concentration of the given pollutant for a given month in $\mathbf{2 0 2 0}$ has to be statistically significantly different than the average concentration of that pollutant in the same month during 2019 and earlier. Secondly, the pollutant concentration in the month with different levels of the concentration compared to the previous years has to be statistically different compared to the concentration before observing the first case of the COVID-19. Finally, the trend analysis has to show a decreasing trend from at least 2019 till 2020.

\section{RESULTS AND DISCUSSION}

Figs. S1(a)-S1(d) presents a map showing COVID-19 affected zones starting from January 20, 2020, according to the situation reports of the World Health Organization (WHO) (WHO, 2020). In less than one month since the first case of pneumonia of unknown etiology had been detected in Wuhan City, Hubei Province, China, the novel virus spread to three neighboring countries: Japan (1), South Korea (1), and Thailand (2) (Fig. S1(a)). Fig. S1(b) shows the global situation about two weeks later on February 1, when the COVID-19 had expanded to the Western Pacific, SouthEast Asia, United States of America, Canada, Europe, and Eastern Mediterranean region, while the COVID-19 outbreak was still largely centered around Hubei Province. Data available from WHO showed that the main mode of transmission was from symptomatic cases.

As reported on March 1 (Fig. S1(c)), the number of globally confirmed cases increased 7.3 times within a 1-month period. There were several new states including Iran, Iraq, UAE, Saudi Arabia, Pakistan, Afghanistan, Mexico, Brazil, Georgia, Azerbaijan, Ecuador, Ireland, Monaco, Norway, Ireland, Estonia, Lithuania, Belarus, the Netherlands, Belgium, Luxemburg, Romania, Greece, North Macedonia, Austria, Croatia, Switzerland, Algeria, Oman, Egypt, Qatar, Nigeria, and New Zealand reporting rising numbers of cases. The world map in Fig. S1(d) displays the pandemic spread as of April 1, 2020.

Based on the experience from the 2003 SARS-Co-V and MERS-Co-V outbreaks, countries around the globe implemented anti-pandemic measures to retard the spread of the virus. Actions enforceable by law such as closing schools and kindergartens, closing non-essential shops (shops and stores apart from food, doctors, and drug stores), closing non-essential industrial production, closing recreational venues and public parks, curfews, social distancing, stay-at-home orders, and total movement control were taken. Such preventive measures lead to reductions in emissions of certain air pollutants and consequently affect global air quality.

\subsection{Global Air Quality}

Fig. 1 presents the average monthly $\mathrm{NO}_{2}, \mathrm{O}_{3}$, and $\mathrm{PM}_{2.5}$ concentrations measured in urban areas on five continents from January to April 2020 as well as the monthly average values 


\section{Continent $\rightarrow$ The Americas $\rightarrow$ Asia $\rightarrow$ Europe $\rightarrow$ Oceania $\rightarrow$ Africa}

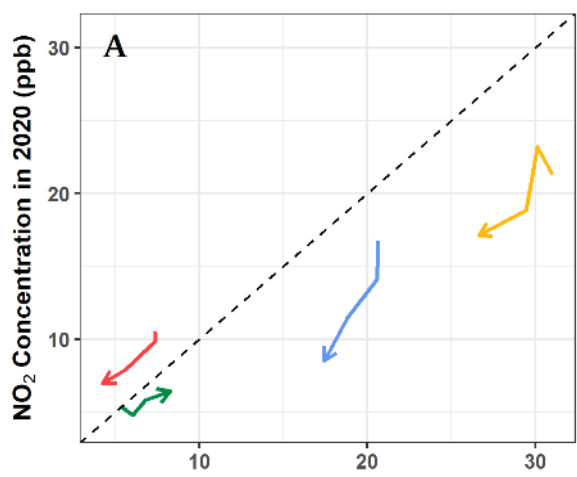

$\mathrm{NO}_{2}$ Concentration in 2017-2019 (ppb)

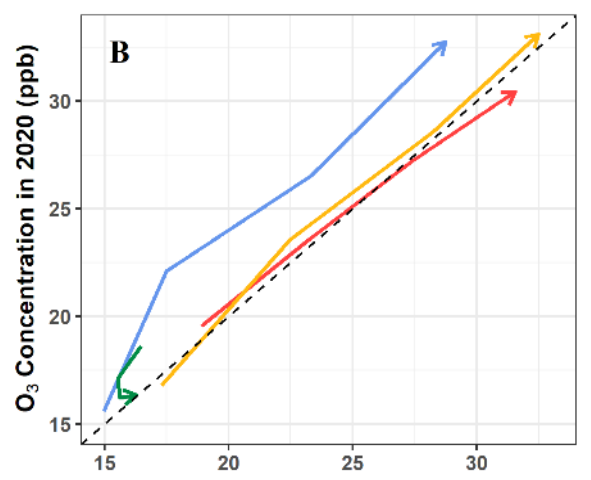

$\mathrm{O}_{3}$ Concentration in 2017-2019 (ppb)

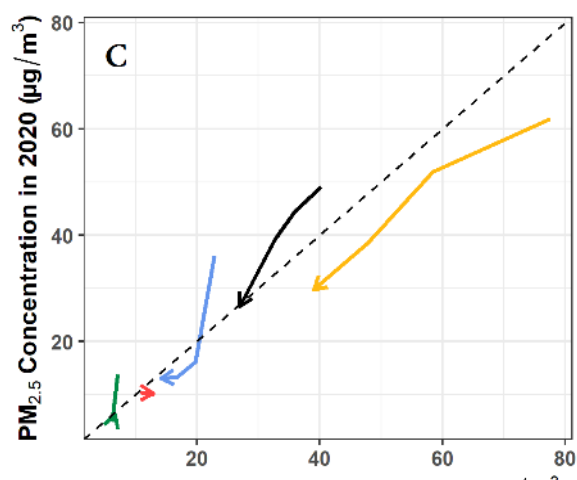

$\mathrm{PM}_{2.5}$ Concentration in 2017-2019 $\left(\mu \mathrm{g} / \mathrm{m}^{3}\right)$

Fig. 1. The average monthly variations of $\mathrm{PM}_{2.5}, \mathrm{NO}_{2}$, and $\mathrm{O}_{3}$ from January to April 2020 and the average 2017-2019 in different continents. The end of the arrow is January, and the tip of the arrow is April- Dotted lines refer to the equal concentration of the given pollutant in 2020 and average 2017-2019.

measured in January to April 2017-2019. In Asia, Europe, the Americas, and Africa, PM 2.5 and $\mathrm{NO}_{2}$ concentrations decreased from January to April (as the arrows go from upper right to lower left), while urban $\mathrm{O}_{3}$ concentration increased. In Oceania that was influenced by the meteorology of the southern hemisphere, $\mathrm{PM}_{2.5}$ and $\mathrm{O}_{3}$ concentrations decreased from January to April while $\mathrm{NO}_{2}$ concentrations increased. Fig. $1(\mathrm{~A})$ shows that the monthly average $\mathrm{NO}_{2}$ concentrations from January to April 2017-2019 were 8.0, 7.7, 6.1, 5.0 ppb (the Americas), 31.0, 30.1, 29.5, $26.6 \mathrm{ppb}$ (Asia), 20.6, 20.6, 18.8, 17.4 ppb (Europe), and 5.3, 6.0, 6.8, $8.3 \mathrm{ppb}$ (Oceania), respectively. While in 2020, due to the COVID-19 preventive measures and the meteorological conditions, the average $\mathrm{NO}_{2}$ concentration dropped to $10.5,9.9,7.9,7.0 \mathrm{ppb}$ (the Americas), 21.3, 23.1, 18.8, $17.1 \mathrm{ppb}$ (Asia), 16.7, 14.1, 11.5, $8.5 \mathrm{ppb}$ (Europe) and 5.4, 4.8, 5.8, $6.4 \mathrm{ppb}$ (Oceania), respectively. Among the four continents, Asia had the highest $\mathrm{NO}_{2}$ concentration from 2017 to 2020. The lowest $\mathrm{NO}_{2}$ concentration over this period was measured in Oceania.

Tables S9-S11 present the percentage change and the statistical analyses of the $\mathrm{NO}_{2}, \mathrm{O}_{3}$, and PM2.5 variations between 2020 (January to April) and 2017-2019 (January-April) averages, respectively. The $\mathrm{NO}_{2}$ concentrations were significantly smaller in 2020 in all months compared to the 2017-2019 averages across all four continents (as the arrows of Fig. 1(A) are located in the lower right below the dotted line) except for January in Oceania (Table S9). Among the four continents, Europe experienced the highest $\mathrm{NO}_{2}$ reduction from February to April 2020 compared to the previous years due to the drastic reduction of on-road diesel vehicles and traffic during the lockdown that are major sources of $\mathrm{NO}_{2}$. The highest $\mathrm{NO}_{2}$ reductions during January were observed in Asia. This ranking among the four continents is consistent with the chronology of the COVID-19 outbreak among the different continents. Since COVID-19 was first observed in Asia very early in 2020, the highest reduction of $\mathrm{NO}_{2}$ in January was observed in Asia. The sharpest European declines in $\mathrm{NO}_{2}$ were in February 2020. Although the COVID-19 outbreak evolved in the Americas after Asia and Europe, controls in the Americas were not as effective as Asia and Europe in reducing the outbreak. Oceania already had the lowest $\mathrm{NO}_{2}$ background compared to other continents. Thus, the change in $\mathrm{NO}_{2}$ in 2020 compared to 2017-2019 was the smallest compared to the other continents.

Fig. 1(B) shows that the average $\mathrm{O}_{3}$ concentrations from January to April 2017-2019 were 18.9, 23.2, 27.4, $31.5 \mathrm{ppb}$ (the Americas), 17.3, 22.5, 28.2, $32.5 \mathrm{ppb}$ (Asia), 15.0, 17.5, 23.3, $28.7 \mathrm{ppb}$ (Europe), and 16.5, 15.5, 15.6, $16.3 \mathrm{ppb}$ (Oceania), respectively. While in 2020 the average $\mathrm{O}_{3}$ concentrations were 19.5, 23.5, 27.2, $30.4 \mathrm{ppb}$ (the Americas), 16.8, 23.6, 28.6, $33.1 \mathrm{ppb}$ (Asia), 15.6, 22.1, 26.5, $32.7 \mathrm{ppb}$ (Europe) and 18.6, 17.1, 16.2, $16.3 \mathrm{ppb}$ (Oceania), respectively. Among the four continents, Asia had the highest $\mathrm{O}_{3}$ concentration in 2020 , followed by the Americas and Europe, while the lowest $\mathrm{O}_{3}$ concentration was observed in Oceania. For all continents except Oceania, urban $\mathrm{O}_{3}$ concentrations increased from January to April. On all four continents, $\mathrm{O}_{3}$ concentrations in 2020 were elevated compared to 2017-2019. However, these increases were 
statistically insignificant in Asia (all months), the Americas (February), and Oceania (March and April) (Table S10).

Fig. 1(C) shows that the average $\mathrm{PM}_{2.5}$ concentrations from January to April 2017-2019 were 12.9, 12.8, 11.0, $12.9 \mu_{g^{-3}}$ (the Americas), 77.5, 58.4, 47.8, 39.0 $\mu_{g^{-3}}$ (Asia), 22.9, 19.8, 16.8, $14.2 \mu \mathrm{g} \mathrm{m}^{-3}$ (Europe), 40.2, 35.8, 32.6, 27.0 (Africa) and 7.0, 6.3, 6.3, $6.7 \mu \mathrm{g} \mathrm{m}^{-3}$ (Oceania), respectively. $\mathrm{PM}_{2.5}$ concentrations from January to April 2020 in the Americas, Asia, Europe (except January) and Oceania (except January) dropped to 10.5, 10.1, 10.4, $10.3 \mathrm{\mu g} \mathrm{m}^{-3}$ (the Americas), 61.9, 51.9, 38.5, $29.7 \mu_{\mathrm{g} \mathrm{m}}^{-3}$ (Asia), 36.1, 16.2, 13.2, $13.0 \mu_{g^{-3}}$ (Europe), and 13.9, 5.9, 5.1, $6.2 \mu \mathrm{g} \mathrm{m}^{-3}$ (Oceania) while it increased to 49.1, 42.3, 39.1, $26.6 \mu \mathrm{g} \mathrm{m}^{-3}$ in Africa (except in April). Among the five continents, Asia and Africa experienced the highest $\mathrm{PM}_{2.5}$ concentrations, followed by Europe, the Americas, and Oceania in 2017-2020. In Asia, Europe, and Africa, PM 2.5 concentrations decreased from January to April, while in the Americas and Oceania, there were fluctuating values. Table S11 shows that in Asia and the Americas, the average PM 2.5 concentration in 2020 declined significantly from January to April 2020 compared to the corresponding months during 2017-2019. Similar significant reductions were observed for Europe (except in January and April) and Oceania (except in January and April). Alternatively, $\mathrm{PM}_{2.5}$ concentrations increased in Africa in 2020 compared to the 2017-2019 averages in all months (except April) and in Europe and Oceania for January. No statistically significant changes in $\mathrm{PM}_{2.5}$ occurred in April 2020 compared to April 2017-2019 in Africa, Europe, and Oceania.

The observed changes in Fig. 1 result from changes in emission rates caused by the COVID-19 preventive measures, changes in the global economy led to reduced industrial emissions (excluding power plants and oil/gas and petrochemical industries), goods transport, and a variety of personal activities such as commuting to work and by differences in meteorological conditions such as temperature, solar irradiance, wind speeds, and planetary boundary layer heights. To focus on the impact of COVID-19 on global air quality, Figs. 2 to 4 present the global maps for the changes in $\mathrm{NO}_{2}, \mathrm{O}_{3}$, and $\mathrm{PM}_{2.5}$ concentrations only during the strict lockdown period (excluding periods of restriction easing (Table S2)) compared to the average concentrations before the first observed case of COVID-19 (for the northern hemisphere) or compared to the average concentration during the same time period during 2017-2020 (for the southern hemisphere). Globally, the $\mathrm{NO}_{2}$ concentration decreased due to the lockdown except in some countries in Western Europe (the Netherlands and Germany), Istanbul, Nur-Sultan, Osaka, and Sydney, where no significant changes in $\mathrm{NO}_{2}$ concentrations occurred. On average, a global $34.0 \%$ reduction in $\mathrm{NO}_{2}$ concentration during the strict lockdown (until April 30, 2020) period was estimated. Major sources of $\mathrm{NO}_{2}$ include transport, including vehicular emissions, especially diesel vehicles, aviation, and ships that were substantially reduced during the lockdown resulting in reduced $\mathrm{NO}_{2}$ concentrations.

Fig. 3 shows that the global average $\mathrm{O}_{3}$ concentration increased by $86.0 \%$ during the strict lockdown period. The $\mathrm{O}_{3}$ concentration increase was expected for three reasons. First, during this period, there were increased temperatures and solar irradiance in the northern hemisphere. Second, the global reduction in nitrogen oxide (NO) emissions reduced the titration of $\mathrm{O}_{3}$ and the formation of $\mathrm{NO}_{2}$. Third, the VOC-limited $\mathrm{O}_{3}$ formation regime (larger $\mathrm{NO}_{x}$ concentration (the sum of $\mathrm{NO}$ and $\mathrm{NO}_{2}$ ) compared to VOCs) can yield higher $\mathrm{O}_{3}$ formation when $\mathrm{NO}_{x}$ was reduced. However, outside of cities and especially in suburban areas where urban air pollution plumes often affect air quality, the reduction of the $\mathrm{NO}_{x}$ and VOCs emissions in the urban core might result in $\mathrm{O}_{3}$ decreases since they are often $\mathrm{NO}_{x}$-limited regimes. The impact of the global pandemic on the $\mathrm{O}_{3}$ concentrations in rural regions is uncertain and requires investigation.

Based on the five years of the data collected in this study (refer to the figures presented in the Supplementary Information), most of the cities included in these analyses were VOC-limited. Thus, increased $\mathrm{O}_{3}$ concentrations were expected as a result of decreased NOx. However, some strongly $\mathrm{NO}_{x}$-limited cities with biogenic or industrial VOC (oil refinery) sources showed no changes in $\mathrm{O}_{3}$ or even decreased $\mathrm{O}_{3}$ concentrations, such as Ahmedabad, India, and Abu Dhabi, United Arab Emirates.

Fig. 4 shows that $\mathrm{PM}_{2.5}$ concentrations were significantly reduced during the lockdown in Asia and South America while it did not change in New York State (NYS), Mexico City, New Zealand, and much of Europe. Increased $\mathrm{PM}_{2.5}$ concentrations were observed in northern France, central Germany, London, and the United Arab Emirates (UAE). Globally, a $15.0 \%$ reduction in the 


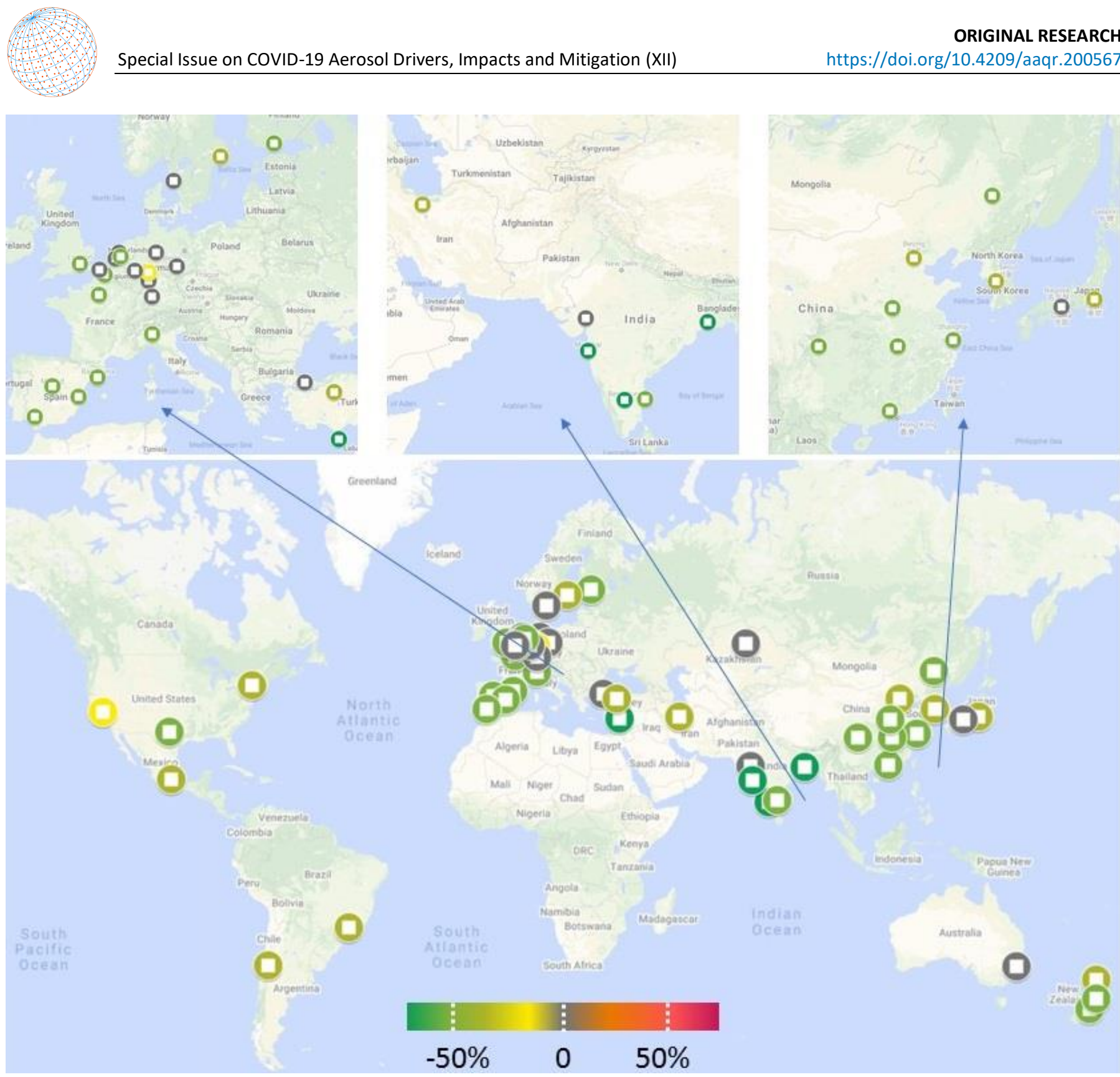

Fig. 2. The global map of $\mathrm{NO}_{2}$ changes during lockdown period in 2020- The percentage values show the changes in the average $\mathrm{NO}_{2}$ concentration of the given pollutant during the lockdown period in 2020 compared the average concentration before observing the first case of COVID-19 in 2020 (for the northern hemisphere) or compared to the average $\mathrm{NO}_{2}$ concentration during the same time period during 2017-2020 (for the southern hemisphere).

average $\mathrm{PM}_{2.5}$ concentration was observed. The increased or constant $\mathrm{PM}_{2.5}$ during the lockdown preventive measures might be attributed to three major causes. First, increased $\mathrm{O}_{3}$ might produce increased secondary organic aerosol (SOA) formation through reactions with olefins (Tobías et al., 2020). Second, new particle formation produces particles more effectively during the lockdown resulting in increased particulate surfaces that enhances heterogeneous chemistry and particle mass (Yao et al., 2018). This mechanism might explain why reductions in transportation and industrial emissions during the lockdown in China did not eliminate severe air pollution episodes (Wang et al., 2020) and haze formation (Le et al., 2020).

Third, in several regions, the lockdown forced people to stay at home in areas where biomass or coal-burning stoves are used for heating and cooking, leading to increased emissions (Amouei Torkmahalleh et al., 2017; Thakur et al., 2020). In many cities, traffic accounts for only 20-35\% (Thakur et al., 2020) of the ambient PM2.5. If the main emissions reductions were caused by major traffic decreases, the $\mathrm{PM}_{2.5}$ reductions would be much less than in $\mathrm{NO}_{2}$. 


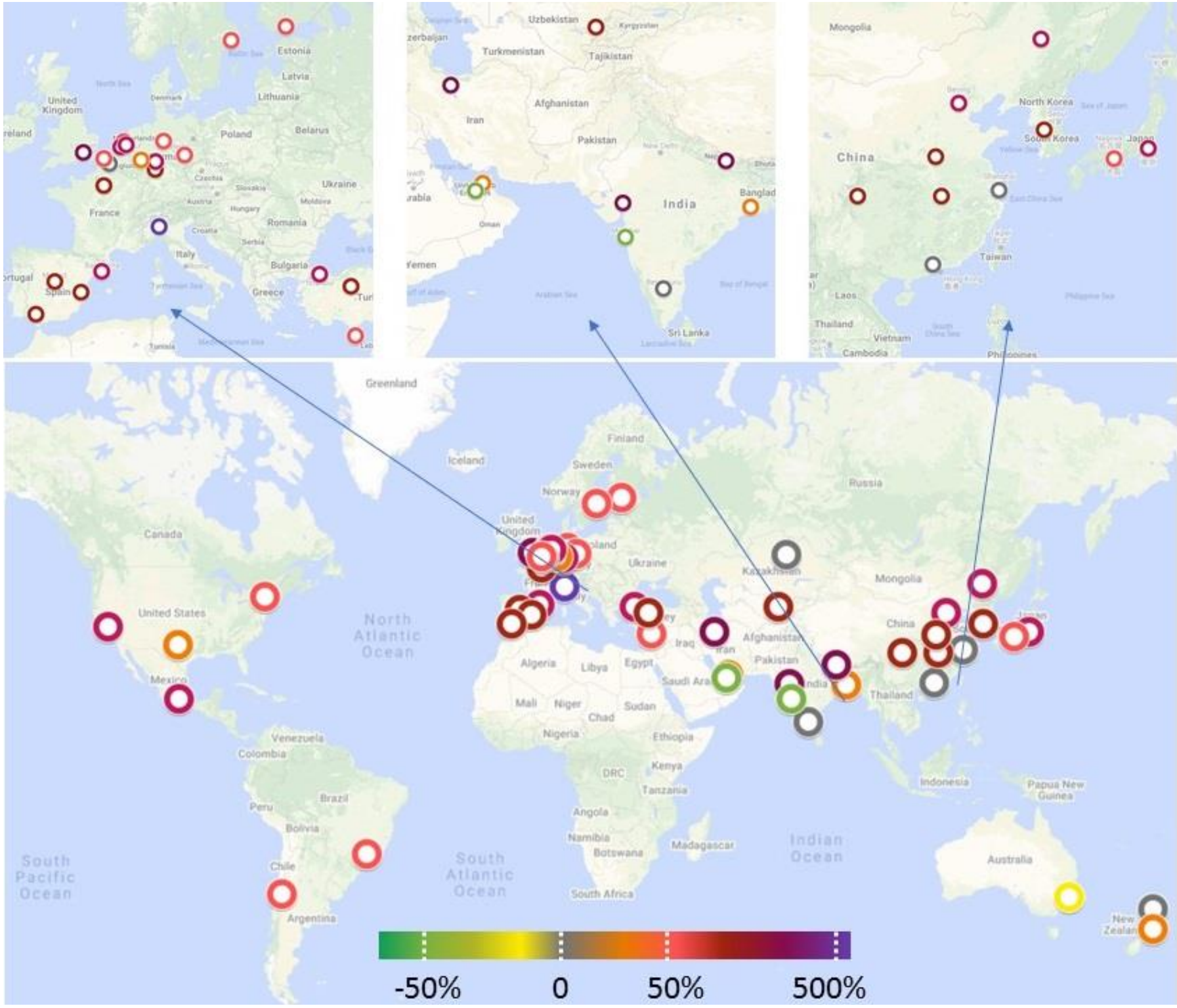

Fig. 3. The global map of $\mathrm{O}_{3}$ changes during lockdown period in 2020- The percentage values show the changes in the average $\mathrm{O}_{3}$ concentration of the given pollutant during the lockdown period in 2020 compared the average concentration before observing the first case of COVID-19 in 2020 (for the northern hemisphere) or compared to the average $\mathrm{O}_{3}$ concentration during the same time period during 2017-2020 (for the southern hemisphere).

Three other seasonal causes could increase $\mathrm{PM}_{2.5}$ during early to mid-spring compared to the late winter that occur annually, distinct from the 2020 lockdown measures. First, in urban areas, around $70 \%$ of $\mathrm{PM}_{2.5}$ tends to be secondary in origin (Amato et al., 2015; Hopke et al., 2020). Complex heterogeneous chemistry and meteorological conditions in China might have favored enhanced formation of $\mathrm{PM}_{2.5}$ as reported by Le et al. (2020) during the COVID19 lockdown. However, increased residential coal and biomass combustion also with spring festival emissions are also likely causes (Dai et al., 2020). Second, this study assumes similar meteorological conditions between 2020 and the previous years. However, in some cities, for example, in the Netherlands, the wind direction might have favored increased $\mathrm{PM}_{2.5}, \mathrm{NO}_{2}$, and $\mathrm{O}_{3}$ concentrations during the 2020 lockdown compared to prior years (Velders et al., 2020). Third, long-range continental transport of atmospheric dust from North Africa to Central Europe and the Middle East in spring (Moulin et al., 1997; Varga, 2020) and inner continental long-range transport of wildfire particles in spring, typically from Russia and Belarus to Finland, could result in increased $\mathrm{PM}_{2.5}$ concentrations (Niemi et al., 2009). 


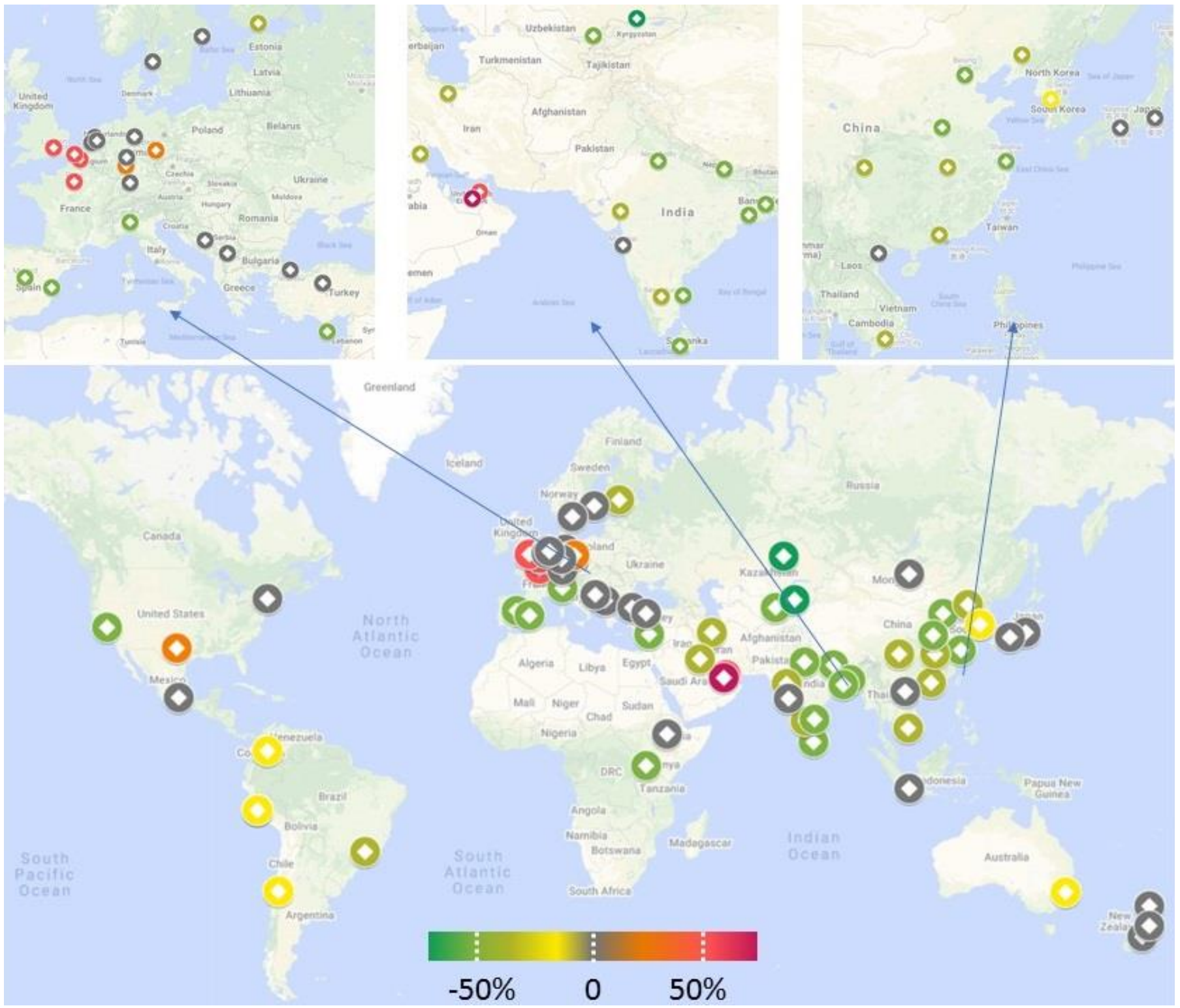

Fig. 4. The global map of $\mathrm{PM}_{2.5}$ changes during lockdown period in 2020- The percentage values show the changes in the average $\mathrm{PM}_{2.5}$ concentration of the given pollutant during the lockdown period in 2020 compared to the average concentration before observing the first case of COVID-19 in 2020 (for the northern hemisphere) or compared to the average $\mathrm{PM}_{2.5}$ concentration during the same time period during 2017-2020 (for the southern hemisphere).

Our analyses showed that $\mathrm{NO}_{2}$ emissions were substantially reduced due to measures taken to prevent COVID-19 and the spreading of the SARS-CoV-2. This reduction also seem to have increased the concentrations of secondary pollutants such as $\mathrm{O}_{3}$, as well as the formation of SOA reflected as a changed composition of $\mathrm{PM}_{2.5}$. Since $\mathrm{NO}_{2}$ seems to be the pollutant highly impacted by the traffic emissions in many cities and because traffic was markedly reduced during the lockdown, $\mathrm{NO}_{2}$ experienced the largest decreases in ambient concentrations.

\section{CONCLUSION}

The unprecedented reduction in global economic activity caused by the COVID-19 related restrictive measures led to noticeable changes in emissions and consequently in ground-level air pollution. Changes in $\mathrm{NO}_{2}$ and $\mathrm{O}_{3}$ surface concentrations are more pronounced and were retained their sign (reduced $\mathrm{NO}_{2}$ and increased $\mathrm{O}_{3}$ ) globally. Long-range transport of particles, the presence 
of natural particulate matter, increased residential emissions, and modified particle formation processes during this period of the generally reduced emissions resulted in compositional changes in $\mathrm{PM}_{2.5}$ as well as an overall decrease in concentrations. However, these reductions came with significant economic (Cutler and Summers, 2020) and other costs (Chandan et al., 2020; Mortazavi et al., 2020; Rosenbaum, 2020). Thus, the air quality improvements would need to be obtained without the extensive other consequences resulting from the imposed reductions in activities.

\section{ACKNOWLEDGMENTS}

The authors of this study truly appreciate the funding provided by Nazarbayev University through the Collaborative Research Grant (grant number: 091019CRP2104). MAT, MN, EA, and $\mathrm{NE}$ are the members of the Chemical and Aerosol Research Team (CART) and also the Environment and Resource Efficiency Cluster (EREC) at Nazarbayev University, and they would like to acknowledge the resources provided by CART and EREC to conduct this research. For India, except for Delhi, daily and hourly averaged air quality data were obtained from the Central Pollution Control Board (CPCB) CCR, OpenAQ or Air quality historical data platform, and location of stations were obtained from the OpenAQ website. CPCB is gratefully acknowledged for making the data available. Further, the CPCB data were consolidated and curated by Mr Prem Maheshwarkar, Earth and Environmental Sciences, IISER Bhopal whose contribution is also acknowledged. In Chile, the contributions made by Mr. Roberto Martinez, Head of the Planning and the Standards, Department of the Air Quality and Climate Change Division, Ministry for the Environment to provide data to this study, are greatly appreciated. In Brazil, CETESB (Environmental Company of the State of Sao Paulo) is acknowledged for its contribution to data preparation. In Cyprus, the authors would like to thank the Department of Labor Inspection of the Ministry of Environment of the Republic of Cyprus for providing the observational data for their monitoring network. For New Zealand, authors acknowledge the Environment Canterbury as the source for the Christchurch data. For Spain, Barcelona, the authors would like to thank "Department of Environmental Quality, Generalitat de Catalunya" as the data source. Turkish Ministry of Environment and Urbanization and Turkish State of Meteorological Services provided air quality and meteorological data, respectively, that are greatly appreciated. In the Netherlands, data were obtained from the National Institute for Public Health and the Environment (RIVM) and contained additional data from the GGD Amsterdam (provided by Dave de Jonge) and the DCMR Environmental Protection Agency (provided by Ed van der Gaag) and National Institute for Public Health and the Environment (RIVM) that are greatly appreciated. The authors would like to thank Tehran Air Quality Control Company for providing the data for the city of Tehran.

\section{COMPETING INTEREST DECLARATION}

The authors declare no competing interests.

\section{SUPPLEMENTARY MATERIAL}

Supplementary data associated with this article can be found in the online version at https://doi.org/10.4209/aaqr.200567

\section{REFERENCES}

Adhikari, A., Yin, J. (2020). Short-term effects of ambient ozone, $\mathrm{PM}_{2.5}$, and meteorological factors on COVID-19 confirmed cases and deaths in Queens, New York. Int. J. Environ. Res. Public Health 17, 4047. https://doi.org/10.3390/ijerph17114047

Amato, F., Alastuey, A., Karanasiou, A., Lucarelli, F., Nava, S., Calzolai, G., Severi, M., Becagli, S., Gianelle, V., Colombi, C. (2015). AIRUSE-LIFE+: A harmonized PM speciation and source apportionment in five southern European cities. Atmos. Chem. Phys. 16, 3289-3309. https://doi.org/10.5194/acp-16-3289-2016 
Amouei Torkmahalleh, M., Gorjinezhad, S., Unluevcek, H.S., Hopke, P.K. (2017). Review of factors impacting emission/concentration of cooking generated particulate matter. Sci. Total Environ. 586, 1046-1056. https://doi.org/10.1016/j.scitotenv.2017.02.088

Andree, B.P.J. (2020). Incidence of COVID-19 and Connections with Air Pollution Exposure : Evidence from the Netherlands. Policy Research Working Paper; No. 9221. World Bank, Washington, DC. https://openknowledge.worldbank.org/handle/10986/33664

Bauwens, M., Compernolle, S., Stavrakou, T., Müller, J.F., Van Gent, J., Eskes, H., Levelt, P.F., van $\operatorname{der}$ A, R., Veefkind, J., Vlietinck, J. (2020). Impact of coronavirus outbreak on $\mathrm{NO}_{2}$ pollution assessed using TROPOMI and OMI observations. Geophys. Res. Lett. 47, e2020GL087978. https://doi.org/10.1029/2020GL087978

Berman, J.D., Ebisu, K. (2020). Changes in U.S. air pollution during the COVID-19 pandemic. Sci. Total Environ. 739, 139864. https://doi.org/10.1016/j.scitotenv.2020.139864

Carugno, M., Consonni, D., Randi, G., Catelan, D., Grisotto, L., Bertazzi, P.A., Biggeri, A., Baccini, M. (2016). Air pollution exposure, cause-specific deaths and hospitalizations in a highly polluted Italian region. Environ. Res. 147, 415-424. https://doi.org/10.1016/j.envres.2016.03.003

Chandan, J.H., Taylor, J., Bradbury-Jones, C., Nirantharakumar, K., Kane, E., Bandyopadhyay, S. (2020). COVID-19: A public health approach to manage domestic violence is needed. Lancet Public Health 5, e309, https://doi.org/10.1016/S2468-2667(20)30112-2

Ciencewicki, J., Jaspers, I. (2007). Air pollution and respiratory viral infection. Inhalation Toxicol. 19, 1135-1146. https://doi.org/10.1080/08958370701665434

Cleveland, R.B., Cleveland, W.S., McRae, J.E., Terpenning, I. (1990). STL: A seasonal-trend decomposition procedure based on loess. J. Off. Stat. 6, 3-73. https://www.wessa.net/downl oad/stl.pdf

Collivignarelli, M.C., Abbà, A., Bertanza, G., Pedrazzani, R., Ricciardi, P., Miino, M.C. (2020). Lockdown for CoViD-2019 in Milan: What are the effects on air quality? Sci. Total Environ. 732 139280. https://doi.org/10.1016/j.scitotenv.2020.139280

Cutler, D.M., Summers, L.H. (2020) The COVID-19 pandemic and the \$16 trillion virus. J. Amer. Med. Soc. 324, 1495-1496 https://doi.org/10.1001/jama.2020.19759

Dai, Q., Liu, B., Bi, X., Wu, J., Liang, D., Zhang, Y., Feng, Y., Hopke, P.K. (2020). Dispersion normalized PMF provides insights into the significant changes in source contributions to $\mathrm{PM}_{2.5}$ after the COVID-19 outbreak. Environ. Sci. Technol. 54, 9917-9927. https://doi.org/10.1021/a cs.est.0c02776

Gupta, D.S. (2020). Why CNN is calling the novel coronavirus outbreak a pandemic. CNN. https://edition.cnn.com/2020/03/09/health/coronavirus-pandemic-gupta/index.html

Hopke, P.K., Dai, Q., Li, L., Feng, Y. (2020). Global review of recent source apportionments for airborne particulate matter. Sci. Total Environ. 740, 140091. https://doi.org/10.1016/j.scitote nv.2020.140091

Karavoulias, A. (2020). Statistical analysis of climate extremes in Greece (1979-2019), M.Sc. thesis, University of Patras. http://hdl.handle.net/10889/13227

Lai, C.C., Shih, T.P., Ko, W.C., Tang, H.J., Hsueh, P.R. (2020). Severe acute respiratory syndrome coronavirus 2 (SARS-CoV-2) and coronavirus disease-2019 (COVID-19): The epidemic and the challenges. Int. J. Antimicrob. Agents 55, 105924. https://doi.org/10.1016/j.ijantimicag.2020.1 05924

Lal, P., Kumar, A., Kumar, S., Kumari, S., Saikia, P., Dayanandan, A., Adhikari, D., Khan, M. (2020). The dark cloud with a silver lining: Assessing the impact of the SARS COVID-19 pandemic on the global environment. Sci. Total Environ. 732, 139297. https://doi.org/10.1016/j.scitotenv.2020.139297

Le Quéré, C., Jackson, R.B., Jones, M.W., Smith, A.J., Abernethy, S., Andrew, R.M., De-Gol, A.J., Willis, D.R., Shan, Y., Canadell, J.G. (2020). Temporary reduction in daily global $\mathrm{CO}_{2}$ emissions during the COVID-19 forced confinement. Nat. Clim. Chang 10, 647-653. https://doi.org/10.10 38/s41558-020-0797-x

Le, T., Wang, Y., Liu, L., Yang, J., Yung, Y.L., Li, G., Seinfeld, J.H. (2020). Unexpected air pollution with marked emission reductions during the COVID-19 outbreak in China. Science 369, 702706. https://doi.org/10.1126/science.abb7431

Mahato, S., Pal, S., Ghosh, K.G. (2020). Effect of lockdown amid COVID-19 pandemic on air quality of the megacity Delhi, India. Sci. Total Environ. 730, 139086. https://doi.org/10.1016/j.scitoten v.2020.139086 
Mortazavi, S.S., Assari, S., Alimohamadi, A., Rafiee, M., Shati, M. (2020). Fear, loss, social isolation, and incomplete grief due to COVID-19: A recipe for a psychiatric pandemic. Basic Clin. Neurosci. 11, 225-232. https://doi.org/10.32598/bcn.11.covid19.2549.1

Moulin, C., Lambert, C.E., Dulac, F., Dayan, U. (1997). Control of atmospheric export of dust from North Africa by the North Atlantic Oscillation. Nature 387, 691-694. https://doi.org/10.1038/ 42679

Nakada, L.Y.K., Urban, R.C. (2020). COVID-19 pandemic: Impacts on the air quality during the partial lockdown in São Paulo state, Brazil. Sci. Total Environ. 730, 139087. https://doi.org/10. 1016/j.scitotenv.2020.139087

Niemi, J.V., Saarikoski, S., Aurela, M., Tervahattu, H., Hillamo, R., Westphal, D.L., Aarnio, P., Koskentalo, T., Makkonen, U., Vehkamäki, H. (2009). Long-range transport episodes of fine particles in southern Finland during 1999-2007. Atmos. Environ. 43, 1255-1264. https://doi.org/10.1016/j.atmosenv.2008.11.022

Rosenbaum, L. (2020). The untold toll - the pandemic's effects on patients without Covid-19. N. Engl. J. Med. 382, 2368-2371. https://doi.org/10.1056/NEJMms2009984

Secon, H., Woodward, A., Mosher, D. (2020). A comprehensive timeline of the coronavirus pandemic at 1 year, from China's first case to the present. Business Insider. https://www.busi nessinsider.com/coronavirus-pandemic-timeline-history-major-events-2020-3

Sharma, S., Zhang, M., Gao, J., Zhang, H., Kota, S.H. (2020). Effect of restricted emissions during COVID-19 on air quality in India. Sci. Total Environ. 728, 138878. https://doi.org/10.1016/j.scit otenv.2020.138878

Siciliano, B., Carvalho, G., da Silva, C.M., Arbilla, G. (2020). The impact of COVID-19 partial lockdown on primary pollutant concentrations in the atmosphere of Rio de Janeiro and São Paulo Megacities (Brazil). Bull. Environ. Contam. Toxicol. 105, 2-8. https://doi.org/10.1007/s0 0128-020-02907-9

Thakur, M., Boudewijns, E.A., Babu, G.R., van Schayck, O.C. (2020). Biomass use and COVID-19: A novel concern. Environ. Res. 186, 109586. https://doi.org/10.1016/j.envres.2020.109586

Tobías, A., Carnerero, C., Reche, C., Massagué, J., Via, M., Minguillón, M.C., Alastuey, A., Querol, $X$. (2020). Changes in air quality during the lockdown in Barcelona (Spain) one month into the SARS-CoV-2 epidemic. Sci. Total Environ. 726, 138540. https://doi.org/10.1016/j.scitotenv.202 0.138540

Varga, G. (2020). Changing nature of Saharan dust deposition in the Carpathian Basin (Central Europe): 40 years of identified North African dust events (1979-2018). Environ. Int. 139, 105712. https://doi.org/10.1016/j.envint.2020.105712

Velders, G.J.M., Willers, S.M., Wesseling, J., Elshout, S. van den, Swaluw, E. van der, Mooibroek, D., Ratingen, S. van. (2021) Improvements in air quality in the Netherlands during the corona lockdown based on observations and model simulations. Atmos. Environ. 247, 118158 https://doi.org/10.1016/j.atmosenv.2020.118158

Wang, P., Chen, K., Zhu, S., Wang, P., Zhang, H. (2020). Severe air pollution events not avoided by reduced anthropogenic activities during COVID-19 outbreak. Resour. Conserv. Recycl. 158, 104814. https://doi.org/10.1016/j.resconrec.2020.104814

Wang, Q., Su, M. (2020). A preliminary assessment of the impact of COVID-19 on environment A case study of China. Sci. Total Environ. 728, 138915. https://doi.org/10.1016/j.scitotenv.202 0.138915

World Health Organization (WHO) (2020). Coronavirus Disease (COVID-19) Situation Report. https://www.who.int/emergencies/diseases/novel-coronavirus-2019/situation-reports

Xu, K., Cui, K., Young, L.H., Wang, Y.F., Hsieh, Y.K., Wan, S., Zhang, J. (2020). Air quality index, indicatory air pollutants and impact of COVID-19 event on the air quality near central China. Aerosol Air Qual. Res. 20, 1204-1221. https://doi.org/10.4209/aaqr.2020.04.0139

Yao, L., Garmash, O., Bianchi, F., Zheng, J., Yan, C., Kontkanen, J., Junninen, H., Mazon, S.B., Ehn, M., Paasonen, P. (2018). Atmospheric new particle formation from sulfuric acid and amines in a Chinese megacity. Science 361: 278-281. https://doi.org/10.1126/science.aao4839

Zoran, M.A., Savastru, R.S., Savastru, D.M., Tautan, M.N. (2020). Assessing the relationship between ground levels of ozone $\left(\mathrm{O}_{3}\right)$ and nitrogen dioxide $\left(\mathrm{NO}_{2}\right)$ with coronavirus (COVID-19) in Milan, Italy. Sci. Total Environ. 740, 140005. https://doi.org/10.1016/j.scitotenv.2020.140005 